\title{
The Use of Authentic Text to Teach Writing Skills to Political Science Students
}

\author{
S. Danilina \\ Taras Shevchenko National University of Kyiv \\ Corresponding author. E-mail: sv.danilina@gmail.com
}

\begin{abstract}
Paper received 26.01.18; Revised 29.01.18; Accepted for publication 01.02.18.
https://doi.org/10.31174/SEND-PP2018-154VI64-04

Abstract. Using authentic materials in teaching ESP is part and parcel of communicative approach methodology. Unadapted materials bring the classroom closer to real-life language use and make language learning more meaningful and engaging for students. Both a challenge and benefit for teachers though is that from a vast array of authentic materials available today, they have to choose the ones which would meet their students' needs and expectations. Based on an ESP class taught to political science students, this article offers a suggestion on how to approach writing skills (namely, using cohesive devices) by analyzing the construction of an authentic article.
\end{abstract}

Keywords: ESP, cohesive devices, political science, communicative methodology, authentic materials.

As Ukraine is heading towards tighter integration with the European Union, the country's higher education curriculum is facing new challenges, striving to update its standards and bring them closer to those of European universities. Teaching English to higher education students is also transforming by adopting contemporary communicative approach in the classroom, which involves task-based learning with a lot of pair- and groupwork in class, roleplay, case study, projectbased methodology, etc. The same principles are applied to teaching English for Specific Purposes (ESP) classes, which make up integral part of English language learning curriculum. This article will discuss the possibilities of using authentic texts in ESP instruction and analyse a case of using an original article written in English in an English class with $3^{\text {rd }}$ year students of philosophy department who read political science as their specialism.

It should be mentioned at the start though that there have been different approaches to defining authentic materials. Because authentic language material is usually viewed as "texts produced by native speakers for a non-pedagogical purpose" [1, p. 459] or "as the material which has not been especially designed for language teaching, but produced for purposes other than to teach language" [6, p. 99], this may question the authenticity of any material once it is brought into a language classroom and used for teaching purposes. Quoting Serbian scholar Savka Blagojevic, not to engage deeper into the discussion "whether authentic materials are only those which belong to the real world and are designed to meet its demands, and not the ones used in a classroom, we shall focus on the language teaching material which comprises authentic texts that have not been written to make up a teaching sample which will be the subject of certain language analyses" [2, p. 116]. In other words, for the purposes of this article, we shall consider authentic the materials which have not been adapted or created to teach language systems or skills.

The distinctive feature of using authentic materials in class is its emphasis on the interpretation of the language sample, with students being as a rule more interested in the content of the presented text than in the language forms available in it. This refers to the language acquisition theory by Stephen Krashen who stresses the importance of the interest that learners have primarily in the content, rather than the form, of the text, which prevents them from consciously concentrating on language forms and thus 'acquire' a foreign language subconsciously [4].

However, there are arguments both for and against the use of such texts. The use of authentic texts in ESP instruction is justified on the assumption that simplified or adapted, unlike the 'real life' material, non-authentic texts which are constructed solely for language teaching purposes cannot provide the material fully appropriate for the classroom: simpli- fied texts usually lack their original and subtle meanings and fail to properly prepare language learners to face real-world situations. In other words, according to Long, "texts in language teaching materials bear little resemblance to the genuine target discourse samples learners encounter in the world outside classrooms", and "every study in which language teaching materials [...] and genuine texts have been compared has found the former to be unrepresentative in important ways" [5, p. 121]. That is why he sees the use of genuine (authentic) texts as a significant element in teaching ESP.

An argument against the use of authentic texts could be that they are written in a language too difficult for language learners to understand. Gilmore emphasises another characteristic of the language complexity of authentic texts used in ESP courses: as authentic texts reflect the real-life language, they contain a great diversity of grammatical and lexical elements, which means that they are much more abundant in language forms than the texts constructed for language teaching purposes [3]. Thus, a necessary prerequisite for using authentic materials in the classroom seems to be the students' certain level of linguistic competency, as well as the prior knowledge of their subject matter. Meanwhile, some authors, for example Torregrosa Benavent and SánchezReyes Peñamaría [9], suggest that students of any level of linguistic competency can be effectively exposed to authentic texts in their classroom, the main idea being to offer students a great number of short authentic texts instead of longer passages. They believe that the quantity of texts will provide a high enough level of frequency of the language elements aimed to be taught in the classroom and will help students recognise them. This is generally seen as the pre-condition and the first stage in acquiring foreign language elements.

Savka Blagojevic remarks that, in order to properly select an authentic text for the ESP classroom, it is necessary, first, to undertake several analyses, namely: " 1 . The needs analysis of students' particular academic discipline, which includes students' both actual and anticipated needs, adjusted to the general and specific objectives of an ESP course; 2. The analysis of students' prior knowledge of a language; 3 . The analysis of students' prior knowledge of a discipline" [2,p.120].

At Kyiv National University students who do not major in philology learn general English for the first two years of studies, and for another two years of their bachelor's programme they are taught ESP depending on their specialism. The expectations of Ukrainian philosophy students as for the outcome of their English studies at the university level are quite traditional and not country-specific: generally they wish to be able to integrate into the international community of philosophy scholars, be able to present in English at conferences, effectively interact with their colleagues from around the world, write articles that would be accepted for publishing in international peer-reviewed journals. A case, 
which is more specific for Ukraine, is that as a rule students are very willing to continue their university studies in European and American colleges and universities, mostly after they gain bachelor's degree in Ukraine, but cases of studying in English (or sometimes German) at foreign universities during their bachelor's programme are also common, mostly provided by different student exchange programmes.

Because the accepted approach to ESP at the university is a competency based method which includes conducting needs analysis at the start of each academic year, the students were surveyed as for the competencies they wanted to achieve during their ESP course. Being able to write articles - both for scientific journals and for the general public, were cited among their priorities. Another important issue, which enables the use of authentic materials, is the students' certain level of linguistic competency, as well as the prior knowledge of their subject matter. The selection of texts and their use in teaching ESP to philosophy students are based on two assumptions: 1) students have reached a high enough level of English grammar, that is, linguistic competence, and 2) students are able to understand language expressions necessary to have a conversation on general topics.

The group for which the authentic text below was chosen is the one of six third-year students all of whom have reached level B2 according to CEFR. They all had had two years of general English instruction, and started their ESP course in the third year of studies. From the point of view of understanding key language expressions used in the article, their linguistic competences were quite sufficient. The reason for selecting this text was to assist students in raising their awareness of a particular functional feature of text writing (in this case, the use of cohesive devices) in constructing English language texts and to activate the language competence which the students already possess. It would also enable them to "relate their newly acquired knowledge and language experience, which are relevant to their future profession, to those previously acquired while learning English for general purposes" [2, p.120].

Language teaching methodologists maintain that comprehension of a foreign language text is achieved through the combination of bottom-up processing (knowledge of lexis and grammar), and top-down processing (knowledge of situational and cultural context, and background knowledge of the topic) [7, p. 41].

The article on the results of parliamentary elections in the Czech Republic was chosen for several reasons:

1) Its topicality for Ukrainian students, as Ukrainian diaspora in the Czech Republic is the biggest, even outnumbering the Slovaks; furthermore, Czech universities are popular with Ukrainian students, especially in terms of pursuing their master's degrees; thus, the prospects of Ukrainian-Czech relations in the aftermath of the elections must be of interest to the students;

2) The article offers examples of cohesive devices (namely, linkers or conjuncts), which our lesson was supposed to highlight, and up-to-date political science vocabulary;

3) The article is compact, therefore rather easy to manipulate within the set timeframe of the lesson.

It is well established by teaching science that the more mental effort is invested into an activity, the better it is likely to be retained. After a short lead-in of introducing the topic of the article and asking the students about their expectations as for the results of the elections, the students were split in 2 groups of three and given the article cut into five pieces (extract 1 - first two paragraphs, extract 2 - paragraph 3 , extract 4 - paragraphs $4 \& 5$, extract 5 - paragraphs $6 \& 7$, and extract 6 - last paragraph).

Below is the text of the article with the cohesive devices (to be more precise, linkers or conjuncts) italicised:

"Ukrainian Ambassador to the Czech Republic Yevhen Perebyinis has said he expects that the future Czech government will continue the course in support of mutually beneficial relations with Kyiv and will maintain common European policy on the Ukrainian issue.

The diplomat said this in a comment to an Ukrinform correspondent.

"I hope that this [future] government will continue to pursue pragmatic and mutually beneficial relations with Ukraine," Perebyinis said.

Despite various estimates of the results of the Czech elections, he is "not inclined to dramatize them." The Ukrainian side is well aware of the ANO party (Action of Dissatisfied Citizens), which triumphed in the October 20-21 elections and without which a government cannot be formed, since it was also represented in the government that completes its cadence. Despite the fact that this political party has views different from "traditional parties" regarding the functioning of the EU (in particular, it opposes the influx of migrants and the introduction of the euro), in principle, it is a proEuropean party, which was confirmed by its leader Andrej Babis. Perebyinis also recalled a statement made by Babis a few days before the election that he did not plan to cooperate in forming a government with pro-Russian parties.

"Therefore, in principle, I hope that the government, which will be formed on the basis of these elections, will be pro-European, and that it will continue the same position that was defended by the current [government] in terms of support for Ukraine in the EU," the Ukrainian ambassador said.

The diplomat said at the same time that the ANO leader had rarely spoken on foreign policy issues. However, there is his absolutely clear position that he condemns the occupation of Crimea by Russia and Russian aggression in eastern Ukraine. On the other hand, in Kyiv "of course, also noted his statement that sanctions against Russia, unfortunately, do not work as they should, and, obviously, the EU should look for more effective means of influence." However, in general, we "expect that the policy of a new Czech government will not go beyond the mainstream of the EU policy."

From the point of view of Ukrainian interests, Babis's position on labor migration deserves attention. Here, Perebyinis said, the ANO leader has a very clear position: in contrast to the Social Democrats, he advocates more active engagement of Ukrainians who, in his opinion, have proven themselves to be an extremely positive factor in the Czech economy over the past decades, to fill more than 200,000 jobs needed by the Czech Republic.

"During the election campaign, the issue of Ukrainian workers and Ukrainians who could work in the Czech Republic was often the subject of disputes between the Social Democratic Party and ANO," the ambassador said.

Overall, judging by the results of the parliamentary elections in the Czech Republic, Perebyinis stated that they had demonstrated the triumph of the protest electorate, while the so-called traditional parties that were in power over the past 25 years received an extremely modest result, including the SocialDemocratic Party, which heads the current government"[10].

Based on the features of the text, in particular, on its cohesive devices, the students had to restore its original form. The easiest part for both groups was to identify the first and last parts, with the fist starting with an introduction of Perebyinis, 
while the last with the linker 'overall'.

The students had difficulty identifying the second part, to make the task easier, their attention was drawn to the pronoun 'he', they had to identify the anaphoric reference of the pronoun (Perebyinis), which helped them restore the text's cohesion. At the same time, the students had to analyse why part 3 and 4 were not a good choice here.

Part 3 would not form a cohesive text with part 1because the phrase starting with 'therefore' does not logically follow from the diplomat's last phrase from part 1. Furthermore, the repetition of the noun 'government', instead of substituting it with a pronoun, and the collocation 'I hope' in two sentences in a row does not seem to be likely. Part 4 sounds too specific for the beginning of the article, adverb 'here' makes it clear that the speaker had dwelled on several issues previously.

At this point, it was easier to locate the part starting with 'therefore'. It logically follows from the previous statement on not planning to cooperate with pro-Russian parties, the adjective 'pro-Russian' matching 'pro-European' by its structure and thus, by repetition of the prefix, representing a lexical cohesive device. Mentioning 'the government which will be formed' matches well the name of the prime minister, which the ambassador referred to in the previous statement.

The part speaking of the narrower issue of Ukrainian interests logically comes closer to the end of the article, exemplifying a traditional organisation of text, from the general to the specific.

In the next stage of the lesson, the students were asked to work in pairs, identify all linkers in the article, and figure out their meanings.

The following linkers were identified and then grouped according to their meanings:

1) contrastive: while, on the other hand, in contrast to; 2) additive: and, also; 3) summative: overall; 4) resultative: therefore; 5) concessive: however, despite (the fact that...).

Cliche 'from the point of view of' can be viewed as a lexical cohesive device, showing a transition to a new topic in the text, and thus also connecting parts of the text.

Special attention was paid to the construction of sentences with concessive linkers. First, another common concessive linker - although/ though - was elicited, and then the students were given two clauses: 'the ANO leader had rarely spoken on foreign policy issues' and 'he clearly condemns the occupation of Crimea', which they had to combine into a compound sentence using various linkers of contrast. Traditionally, the students are confused with the difference in the construction of sentences with linkers 'however' and 'although', as well as 'despite' and 'in spite of', after which they tend to put a clause, without adding the phrase 'the fact of'. As a rule, students need more exercises to gain confidence with linker usage. One of such exercises could be displaying the gapped text of the article on IWB and asking students to fill in the gaps with the corresponding cohesive devices.

In the next stage of the lesson, the students were asked to work in pairs and pick the collocations from the article that they find useful for discussing the article's topic, try to memorise them and check their memory in pairs. After which, the whole class discussion of the Czech elections and possible prospects for Ukraine followed.

As homework the students were asked to write a follow up 300-word essay on their opinion of the topic, paying attention to its cohesion and using (but not overusing) appropriate linkers.

To sum up, an authentic text (in this case, a newspaper article) can be a valuable source of linguistic features that the student would like to raise their awareness of. Various strategies that allow to analyse the text from several perspectives and appeal to different learning styles can enhance the consciousness of learning, which results in better retention of the material and the use of the learnt material in practice. Cohesive devices is a notoriously difficult feature to master in a foreign language text, which could result in EFL students' text lacking them and therefore appearing 'telegraphic', or, on the other hand, overusing them, with their text sounding unnatural as a result. As Scott Thornbury points out, " an overemphasis on teaching conjuncts $[. .$.$] at the expense of a$ focus on other ways of making texts cohesive, can result in [...] stilted, overconnected type of text" [8, p. 33]. This can be caused by a "pre-occupation with 'bottom-up processes, as opposed to top-down ones" [8, p. 33]. Further research can be connected with working out efficient strategies of analysing text as a whole, rather than looking at it on sentence by sentence level, viewing it 'from above', which can allow to avoid unnecessary overuse of linkers.

\section{REFERENCES}

1. Bacon S., Finneman M. A study of attitudes, motives, and strategies of university foreign language students and their disposition to authentic oral and written input // Modern Language Journal, 1990. No.74 (4). - pp. 459-473.

2. Blagojevic S. Original Texts as Authentic ESP Teaching Materialthe Case of Philosophy [Electronic resource] // ESP Today, 2013. Vol. 1 (1). $\quad-$ pp. 113-126. - Available at: https://www.esptodayjournal.org/pdf/vol_1_1/7.\%20SAVKA\%20 BLAGOJEVIC-\%20full\%20text.pdf

3. Gilmore A. Authentic materials and authenticity in foreign language learning // Language Teaching, 2007. - No. 40 (2). - pp. 97-118.

4. Krashen S. Principles and Practice in Second Language Acquisition. $-1^{\text {st }}$ Internet Edition, 2009. - 202 p.

5. Long M. Problems in SLA. New Jersey: Lawrence Erlbaum, 2007. $-212 \mathrm{p}$.
6. Nunan D. The Learner-Centered Curriculum. - Cambridge: Cambridge University Press, 1988. -212 p.

7. Thornbury S. An A-Z of ELT. - 1st ed. Macmillan Publishers Limited, 2006. $-256 \mathrm{p}$.

8. Thornbury S. Beyond the Sentence. Introduction to Discourse Analysis. - 1st ed. Macmillan Publishers Limited, 2005. - 192 p.

9. Torregrosa Benavent G., Sánchez-Reyes Peñamaría S. Use of authentic materials in the ESP classroom [Electronic resource] // Encuentro, 2011. - No. 20. - pp. 89-94. - Available at: https://files.eric.ed.gov/fulltext/ED530013.pdf.

10. Ukrainian Ambassador Not Inclined to Dramatise Results of Elections in Czech Republic [Electronic resource] // Ukrinform. Available at: https://www.ukrinform.net/rubric-society/2329494ukrainian-ambassador-not-inclined-to-dramatize-results-ofelections-in-czech-republic.html

Использование аутентичного текста для обучения студентов-политологов навыкам письма на английском языке С. Ю. Данилина

Аннотация. Использование аутентичных материалов в преподавании английского языка для профессиональных целей (ЕSP) является неотъемлемой составляющей коммуникативной методики обучения. Неадаптированные материалы приближают обучение английскому к реальным условиям использования языка и делают обучение более осмысленным и мотивирующим для студентов. В статье предлагается вариант обучения навыкам письма (в частности, правильному использованию средств когезии текста) на основе текстологического анализа аутентичной газетной статьи.

Ключевые слова: ESP, средства достижения когезии текста, политология, коммуникативная методика, аутентичные материальл. 